\section{Using Writing in Horticultural Education}

\author{
R.D. Berghage and \\ N.K Lownds
}

Additional index words. expressive, transactional

Summary. Writing is an integral part of a career in horticulture. Most successful horticulturists write not only in communicating with peers, but also in keeping extensive journals or records of their activities. These tasks use different writing skills. Writing in horticulture classes should reflect, encourage, and provide practice in both types of writing. Assignments should reflect the students' career choices and provide writing practice in an appropriate genre.

$\mathrm{T}$ he national press has covered the inadequacies in the educational system of the United States. Most college professors probably agree that the general literacy skills of many students are below desirable standards, both before they begin college and after they finish. It is easy for faculty in the scientific disciplines to blame the English department. We should, however, refrain from passing the buck. It remains our responsibility to teach our students to use, hone, and improve their writing skills so that they can succeed in their chosen profession.

While most horticulture professors are truly interested in improving their students' ability to write, and thereby their educational experience, requiring professors to assign and grade more writing is a poor solution to the problem. Grading numerous and lengthy papers is tedious and timeconsuming. Most horticulture professors have dual appointments, with research and/or extension comprising a large portion of their responsibilities. Whether we admit it or not, there is a relatively low professional return on

Department of Agronomy and Horticulture, New Mexico State University, Las Cruces, NM 88003

New Mexico Agricultural Experiment Station Journal Article 1566 time invested in reading and grading student papers. What can be done to realities of the higher educational system? The answer lies in limiting the number of graded assignments and the time required to grade the assignments, while increasing the quality of the assignments.

A professor should have a clear idea as to the purpose of every writing assignment before the assignment is made. Assignments should be tailored to accomplish their purpose, and it should be clear to the student how and why the assignment should be done. For an expanded discussion see Fulwiler and Jones (1982). Many assignments, particularly laboratory reports and term papers, all too often become self-perpetuating traditions. "This is what I had to do as an undergraduate, and my students will do it, too."

Britton (1975) describes two roles of a writer that form opposite poles of a spectrum of the purpose of writing. The writer is either a participant (transactional writing), using language to get something done, or a spectator (poetic writing), using language to relive the past. Between these poles Britton describes expressive writing as the category combining both roles. Examples of expressive writing include notes and drafts intended for the authors' use, letters to friends, and personal journals. These writing categories provide a useful means to examine the types of writing a horticulture graduate might be expected to use.

An interesting and useful exercise to determine the types of writing a horticultural professional will need in his or her career is to make a writing pie (Burnham, 1986). This exercise involves keeping a record of all your balance students' needs against the

writing during a 1- or 2-week period, then categorizing the writing according to type (Fig. 1). In this example, about $40 \%$ of the writing was notes intended for the authors' use (lab notebooks and library notes). This was clearly expressive writing. It included not only information, but also passing thoughts, feelings, and an occasional inspiration. About $20 \%$ of the writing was preparation of class notes for lectures, reviews of two papers, and several personal letters, again primarily expressive writing. The remaining $40 \%$ of the writing was transactional, including memoranda to colleagues, instructions to student labor, and the writing of professional papers.

This distribution ofwriting types is not unusual. Most successful horticulturists keep extensive notes on what they do and why they do it. This thinking-on-paper is expressive writing. It provides a record of thoughts and observations and allows you to come back to them in the future. This can be invaluable, as a grower trying to determine what went wrong or a scientist about to write a paper will readily admit. In the past, many educated people kept journals. Darwin, for example, filled numerous notebooks with his observations and thoughts. Today's best students know how to take notes in lecture, but somehow fail to grasp the value of this behavior outside the classroom.

Horticulture faculty are not teaching students the value of writing for themselves. This may be because expressive writing is difficult to evaluate. When students know their writing will be evaluated, it changes the way they think about and complete the writing assignment. The writing is no longer for themselves, but, rather, is for the instructor. Therefore, writing

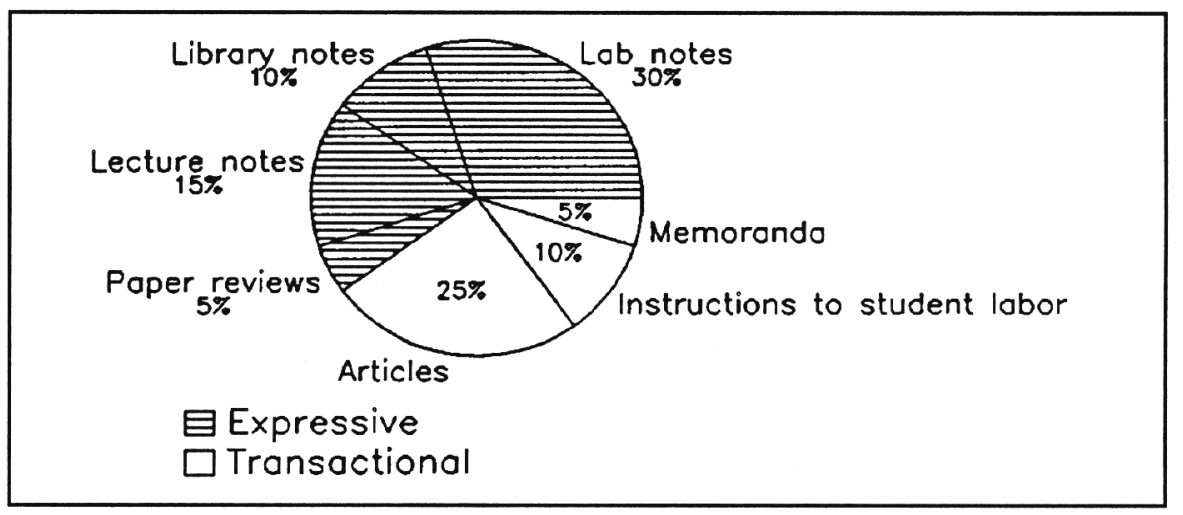

Fig. 1. Writing pie based on writing record of R.D. Bergbage from 3 Sept. 1990 to 17 Sept. 1990. 
in horticulture classes tends to be exclusively formal and transactional. As an example, the graded laboratory notebooks students must keep tend to be very different than the notebooks (journals) faculty keep of their own experiments. Realistically, if students are to learn to keep and use a journal, the journal must be an integral part of the learning experience, and there must be an obvious benefit to the student associated with keeping the journal. This does not mean the journal must be collected and graded. Quite the contrary, student journals should be handled more like faculty notebooks. The benefits of keeping a journal can be demonstrated by incorporating information that should be recorded in the students' journals into "openjournal" essay exams and written assignments. Allowing students to use their journals to complete these assignments and exams will reinforce directly the habit of maintaining comprehensive journals. Because the journal content is tested indirectly with these questions, there is no need to grade the journal itself, thus limiting the time and effort required of the instructor. Keeping journals in class also teaches students a record-keeping skill that will be of great value in their future careers.

Most horticulture students find jobs in one of three broad categories, each of which includes many career choices and opportunities for entrepreneurship. They become educators, either at the high school or college level; extension personnel with industry (i.e., public relations) or the public sector (county agents, $4 \mathrm{H}$, etc.); or they may go into industry, either in production, including the service sector, or production support, such as marketing, sales, and management. Most of these careers require a great deal of genre-specific, transactional writing. Many horticulture class assignments do not reflect appropriate genre. It seems sensible to tailor writing assignments to give students practice in the types of expressive and transactional writing associated with their job choices. Table 1 contains examples of questions that could be used to incorporate the journal and a genre-specific transactional writing task.

One interesting and successful way to include genre-specific writing is through the microtheme, an essay so short it can be typed on a single $5 \times 8$ -

\section{1) Genre: Grower/Manager, commercial greenhouse}

You are in charge of plug production for New Mexico Bedding Plants Inc. Your boss has just hired an assistant for you (a high school student). You want this person to take over the daily routine jobs, starting with watering. Write a list of instructions for this assistant.

\section{2) Genre: Production/Marketing Manager}

Write a memo to the sales department detailing required handling for unrooted mum cuttings.

\section{3) Genre: R\&D Director, commercial horticulture operation}

Write a product development report, including methods, results, and recommendations (based on lab experiment).

\section{4) Genre: High School Instructor}

Develop a laboratory exercise sheet for a high school horticulture class.

\section{5) Genre: College/Junior College Instructor}

Summarize the following article from the American Society for Horticultural Science so it can be used as one lecture in an introductory horticulture course.

\section{6) Genre: Extension/Public Relations Specialist for a retail nursery chain} Given the following sets of data on the effects of fall fertilization on terminal shoot growth and winter hardiness, write a recommendation for homeowners for fall fertilization of trees/shrubs to assure the highest-quality plants next spring.

\section{7) Genre: Extension-public sector}

Write a lesson plan for a master gardener program on air layering.

\section{8) Genre: Sales/Marketing}

Write a short letter to a prospective client explaining the advantages of using cuttings from culture-indexed plants.

inch notecard (Work, 1979). Generally, all students are given the same assignment, along with the evaluation criteria for the theme. Because the writing is used as a mode of learning, students are encouraged to work together outside of class to expand their active thinking time. These essays can be graded rapidly and thus are adaptable to large classes. Rather than writing comments on each microtheme, the instructor can discuss them in general. Graduate assistants or top undergraduates might be trained to grade the microthemes in large classes.

Microthemes are an excellent tool to promote discipline-specific thinking skills. Successful microtheme assignments we have used include the: 1) summary-writing microtheme, 2) thesissupported microtheme, 3) data-provided microtheme, and 4) quandary-posing microtheme. For an expanded discussion see Beau et al. (1982). In each type of microtheme, the assignment can ad- dress questions and problems that require analysis and integration of information. Microtheme questions also can be designed to be genre-specific (Table 1).

The formal term paper is commonly a severe violation of appropriate genre. The paper is written because of and for the professor. The standard term paper format is very different than the magazine articles, extension bulletins, lesson plans, newspaper articles, product and production reports, promotional material, and consumer information flyers students might be expected to write as a part of their careers. The formal term paper is not even a particularly good preparation for the scientific article, which focuses on the analysis and interpretation of data. At best, formal term papers prepare students to write book chapters or review articles, but these opportunities are rare.

The term paper can be much more meaningful if the student is allowed to select a more appropriate genre, such 


\section{TEACHING METHODS}

as a-magazine article or an extension publication. This not only provides the student with a more identifiable final product, but the real-life reward of publication for the best papers is available. Publication could be something as simple as binding the papers and placing them in a departmental library. A better choice, perhaps, might be to use publication outlets that welcome well-written student papers, i.e., extension bulletins, newsletters, and magazine and newspaper articles. The possibility of actual publication will motivate students.

Because much of the time spent working on a paper is spent in review (Fulwiler, 1982), it is appropriate that students also be involved in this process. This can be done by requiring students to have their papers reviewed by another student before turning them in. Research shows that this is probably as effective as instructor-provided feedback (MacAllister, 1982). The students then can be required to turn in both the reviewed draft and a corrected copy. Students can be graded on both their review (of another student's work) and their own paper. This process should reduce the number of substandard papers turned in and make reading and grading the papers much easier.

There can be little doubt that improving a student's ability and motivation to observe and record thoughts and actions will make that person a better horticulturist, and providing classroom opportunities to practice such skills can help achieve this end.

\section{Literature Cited}

Brittton, J. 1975. The development of writing abilities. Macmillian, London. p. 11-18.

Bean, J.C., D. Drenk, and F.D. Lee. 1982. Microtheme strategies for developing cognitive skills, p. 27-38. In: C.W. Griffin (ed.). Teaching writing in ail disciplines. Jossey-Bass Inc., San Francisco.

Burnham, C.C. 1986. The consequences of collaboration: Discovering expressive writing in the disciplines. The Writing Instructor. 6(1):17-24.

Fulwiler, T, and R. Jones. 1982. Assigning and evaluating transactional writing, p. 45-55. In: T. Fulwiler and X. Young (eds.). Language Connection. Natl. Counc. of Teachers of English, Urbana, Ill.

Fulwiler, T. 1982. Writing: An act of cognition. p. 15-26. In: C.W. Griffin (ed.). Teaching writing in all disciplines. JosseyBass Inc., San Francisco.
MacAllister, J, 1982. Responding to student writing. p. 59-66. In: C.W. Griffi (ed.). Teaching writing in all disciplines. Jossey-Bass Inc., San Francisco.

Work, J.C. 1979. Reducing three papers to ten: A method for literature courses. In: G. Stanford (ed.). How to handle the paper load: Classroom practices in teaching english. Natl. Council of Teachers of English, Urbana, Ill. 